\title{
Microgrid With a 3.4 kWp Photovoltaic System in the Universidad Técnica de Manabí
}

\author{
$\underset{\text { CrossMark }}{\text { teick tor updates }}$ \\ Wilber Manuel Saltos Arauz a; Gabriela Intriago Cedeño b; Susana Salvatierra Chávez c; \\ Antonio Vázquez Pérez ${ }^{d}$, María Rodríguez Gámez ${ }^{\mathrm{e}}$
}

Article history: Received 20 March 2017 ; Accepted in revised form 28 July 2017 ; Approved 20 August 2017 ; Available online 31 August 2017

Correspondence Author ${ }^{\text {a }}$

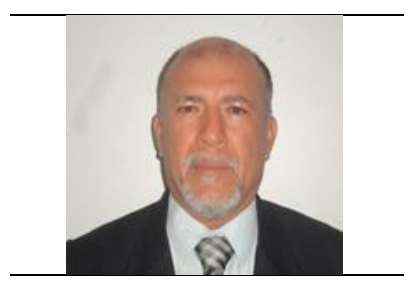

Keywords

Microgrid;

Photovoltaic systems;

Power generation;

Power system reliability;

Quality of service;
Abstract

The emergence and development of Microgrids emerge as an alternative to the distributed generation that is becoming more and more effective at an international level. The research aims to perform an analysis on the behavior of na microrred designed in an urban environment operating connected to the main electrical network or outside it. A technical evaluation of the connected photovoltaic power plant is carried out as a microrred obtaining as a result the improvement of the profiles of voltage, current and apparent power, at the same time that it favors the reduction of the electric energy consumption of the conventional network, with the potential to decrease The amount of the electric bill, contributing to the reduction of oil consumption and $\mathrm{CO}_{2}$ emissions to the atmosphere.

e-ISSN : 2550-6943, p-ISSN : 2550-6951@ Copyright 2017. The Author. SS Journals Published by Universidad Técnica de Manabí.

This is an open-access article under the CC BY-SA 4.0 license (https://creativecommons.org/licenses/by-sa/4.0/) All rights reserved.

a Doctor Aspiring, Universidad Técnica de Manabí, Faculty of Mathematical, Physical and Chemical Sciences, Portoviejo, Manabí, Ecuador

b Electrical Engineer, Universidad Técnica de Manabí, Faculty of Mathematical, Physical and Chemical Sciences Portoviejo, Manabí, Ecuador

c Electrical Engineer, Portoviejo, Manabí, Ecuador

d Doctor Aspiring Universidad Técnica de Manabí, Faculty of Mathematical, Physical and Chemical Sciences, Portoviejo, Manabí, Ecuador

e Ph.D. Universidad Técnica de Manabí, Faculty of Mathematical, Physical and Chemical Sciences, Portoviejo, Manabí, Ecuador 


\section{Contents}

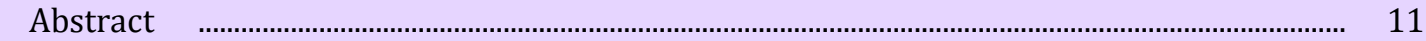

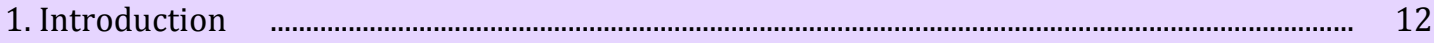

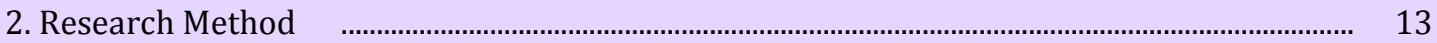

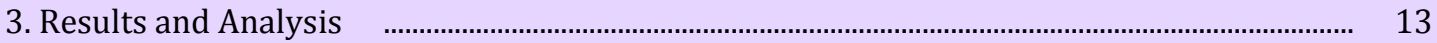

3.1 Evaluation of a mirco-grid in the urban environment: case study Universsidad Tecnica de Manabi ..................................................................................................................................................... 13

3.2 Result of the technical evaluation ...............................................................................................

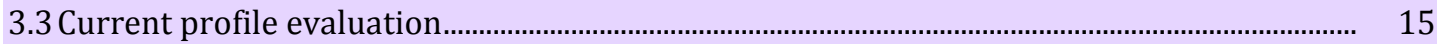

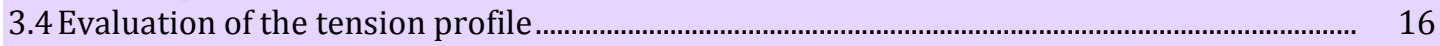

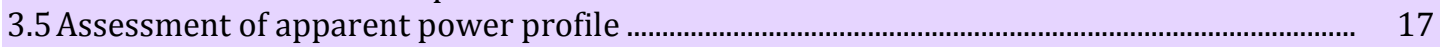

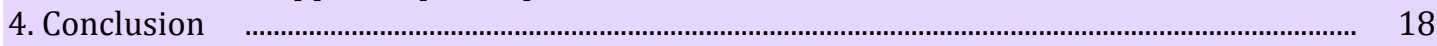

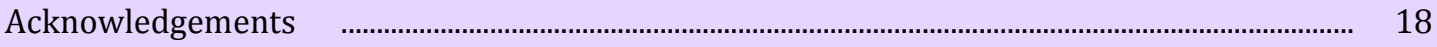

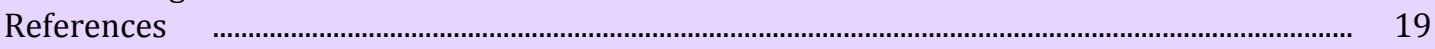

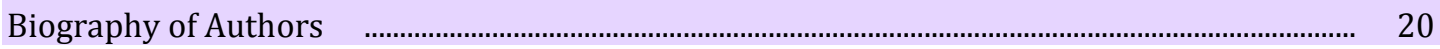

\section{Introduction}

The energy crisis is a problem that affects all sectors of society, a clear example is an increase in the price of electric energy. As a result of this problem, the Faculty of Mathematical Sciences, Physics and Chemistry, and especially the Electricity career, intends to look for alternatives that allow to reduce the expenses derived from the electric bill, at the same time that it is possible to reduce the energy consumption of the centralized system, favoring the saving of fuel and the reduction of the $\mathrm{CO}_{2}$ emissions to the atmosphere

The traditional electrical system has been based on management that allows the energy stored by nature itself for years in the fossil fuels. The transition to a new energy model will be subject to the overcoming of certain technological barriers due to the randomness of the sources of renewable generation. The current penetration of renewable generation systems in the electricity network, especially with the developments obtained for wind and photovoltaic energy, begins to cause impacts in the electricity network, such as the variation of the magnitude of the supply voltage and the increase of the imbalance between active and reactive power between generation sources [1].

But this scheme has some technical disadvantages since large plants are generally very far from the centers of consumption and the transport of these volumes of energy implies a great infrastructure and high losses. Modern electrical power systems (SEPs) are characterized by their high complexity and constant expansion, both geographically and in their power, in parallel with the increase in the demand served by these, the loads have increased their requirements as to the quality of service.

The consequences of the natural disasters that have occurred in recent years have put into question the reliability and quality of the product supplied by the electricity companies. New technologies such as energy storage, fuel cells, renewable energy generation, and network automation are stimulating the idea that users can own, control and operate their own power system [2].

The first years of the 21st century have witnessed the growth and development of microgrids, which are becoming more present in conferences, congresses, publications and in the social field as something very popular, with the foresight of analysts that they can contribute Billions of dollars in potential revenue over the next five years [3].

Current electricity distribution networks operate close to their maximum capacity and must adapt to frequent changes to address environmental challenges and improve their confidence and sustainability. These challenges are met through effective integration and coordination of distributed generators (DG), which facilitates the exploitation of renewable resources [4]. 
It can be said that microgrids as a technical concept are not a new phenomenon. They arise in the year 1882 when Thomas Edison constructed the generation station on Pearl Street in New York. Centralized systems were then developed, but microgrids continued to exist to ensure emergency service in the event of a lack of conventional network services, such as hospitals, lights and rescue equipment, and other social functions that should not be interrupted. When Lasseter introduced the subject of microgrids in 2002, he proposed it as an approximation that considers generation and associated loads as a subsystem or microgrid [2].

But today microgrids take on new strength as a safe alternative to reduce environmental impacts, save fossil fuels, reduce the cost of energy generated and served and increase the efficiency and quality of electric service, enabling users to consume and control their Energy can be generated.

\section{Research Method}

It is made the characterization of the area chosen for the study, taking into account the incident solar potential and the possibilities of its use for the generation of electricity, the solar radiation database was used: global datasets published by NASA [6] , As well as an evaluation of the quality of the electricity network using the Sentron PAC 3200 network analyzer [7], the demand in day and night demand, the voltage and current of the power line before and after the installation.

\section{Results and Analysis}

\section{An approach to the concept of microgrids}

Beyond the debate on the concept of microgrids can be defined as an aggregation of electrical elements in low voltage generation, storage and loads (users), which are grouped in a certain geographical area, which can operate connected to The network or in isolation. The generators can be of different nature, among which are: micro turbines, reciprocating engines such as diesel or gas-based generators, or renewable sources such as wind turbines and photovoltaic systems. For purposes of the electric company, the microgrid is seen as a single charge that can be controlled in magnitude [8].

For consumers, the microgrid can be designed to meet their particular needs, such as increased local reliability, reduction of transport losses, local voltage support, among others [9].

A microgrid has the ability to operate interconnected to the main power grid, where the additional need for power is supplied from it, and when it has surpluses can be braided with the network. Or, they can operate in an isolated condition, a situation that is caused by an obligatory cause, such as a natural disaster; By a need as in remote communities; Or by choice as in certain special applications, an example is computer data centers. In this latter mode, the microgrid generates the power internally, including the transfers between the storage units, so that the supply-demand balance can be achieved [10].

Compared to the traditional grid, micro-networks can offer many benefits, which depend on the point of view to be analyzed [10]:

According to the electrical system: The main advantage is that it is taken as a single controlled entity, which is combined with an interface based on power electronics, which makes it self-sufficient, which includes control, communications, and autonomous protections.

According to users: The biggest benefit is to increase levels of reliability and security, from the environmental point of view: The contribution is to reduce pollutant emissions because they facilitate the introduction of distributed generation and where renewable energy sources are integrated and generated close to the consumer.

\subsection{Evaluation of a micro-grid in the urban environment: case study Universidad Técnica de Manabí}

The High House of Studies is located in the city of Portoviejo in the province of Manabí in Ecuador. It has an enrollment of more than eleven thousand students with more than one

Arauz, W. M. S., Cedeño, G. I., Chávez, S. S., Pérez, A. V., \& Gámez, M. R. (2017). Microgrid with a $3.4 \mathrm{kWp}$ photovoltaic system in the Universidad Técnica de Manabí. International Journal of Physical Sciences and Engineering, 1(2), 11-20. https://doi.org/10.21744/ijpse.v1i2.34 
thousand three hundred workers among professors, researchers, administrative and service personnel. The institution is one of the customers with a high consumption of electricity, which implies the monthly disbursement of a lot of economic resources and a high consumption of oil for the generation of electricity.

During the year 2015, the management of the institution outlined the strategy of developing a project aimed at improving efficiency and energy savings on the university campus and at the same time could lead to a reduction in the bill paid to the electricity company.

The project was aimed at demonstrating technically the potential of a micro-grid built by introducing a photovoltaic power plant connected to the low-voltage grid in the N $\circ 3$ building of full-time teachers, in order to avoid the consumption of part of the energy Of the conventional grid, that can reduce the amount of the electric bill, promoting an improvement in the quality of electric service and contribute to the saving of oil, as well as the reduction of $\mathrm{CO}_{2}$ emissions to the atmosphere.

In order to carry out the study it was necessary to measure certain technical parameters of the network before and after the installation of photovoltaic technology. For this purpose, the Sentron PAC 3200 network analyzer was used, which is simple, inexpensive, user-friendly and easy-to-use equipment that allowed the key results to be obtained for the evaluation of the project.

The Sentron PAC 3200 is a device that has a series of useful functions of monitoring, diagnosis and technical service, as well as an active and reactive energy meter. It has a compact design and represents an ideal replacement for conventional analog instruments, with a wide measured voltage range [7].

The Sentron PAC 3200 can be connected at low voltages of $690 \mathrm{~V}$, as in direct connections up to $500 \mathrm{~V}$ and for higher voltages, you must use voltage transformers as well as to measure currents your own current transformers that come in various sizes. It has easy to use the software. It has two simulation programs to be installed on the PC, offers a friendly understanding of the different tasks performed by the equipment, as well as the different variables that can be displayed, presented in the simulation program and also directly on the screen of the team [7].

With the use of the Sentron PAC 3200 network analyzer, you can obtain more than 50 measured values with maximum and minimum values, with a margin of error of $0.5 \%$ of the measured value. The PAC 3200 data visualization software supports all IBM/AT compatible PC platforms. The connection that is made is point-to-point and you can use an Internet cable that connects from the computer to the PC [7].

If there is a good connection between the Sentron PAC 3200 and the PC, it is guaranteed to display all the readings on the screen and to start saving the information, which is programmed for a maximum of two days with minute-by-minute data records. The program data are provided in Excel sheets, which allows the facility to be studied and where it is possible to perform the graphing of the recorded information and proceed to its visualization. The data record that was used for the study corresponds to: current; Tension and; Apparent power in the different lines that feed the building.

The installation that is feeding the building No3 where the project was carried out, comes from a branch of the UTM, which arrives at a three-phase shielded transformer of $75 \mathrm{kVA}$, which has a voltage of $220 \mathrm{~V}$ to $120 \mathrm{~V}$. Of the transformer by the Secondary the power needs that the building needs, which is distributed to a general board that is located in the low silver of the building.

The board consists of 4 bars which are: line 1 (L1); Line 2 (L2); Line 3 (L3) and; Neutral line (LN), those that carry voltages of $\mathrm{LN}$ that is of $120 \mathrm{~V}$ and also voltages of LL that is $220 \mathrm{~V}$. In the general board, there are 9 breakers from which the power is distributed for each floor of the building. On each floor have three breaker boxes, of which two are used for power and lighting circuits and the third for breakers of air conditioners, each breaker box has voltages of $120 \mathrm{~V}$ 220V-360V. 
The building is composed of several offices of teachers and bathrooms. It is currently consuming a daily equivalent of $68 \mathrm{kWh}$, of which $57 \mathrm{kWh}$ corresponds to consumption during daylight hours when solar energy is available to be used. Figure 1 shows the graphical relation of the energy consumption between the hours of the day and the night, as it is possible to be observed the greater percentage of consumption is realized in the hour of the day.

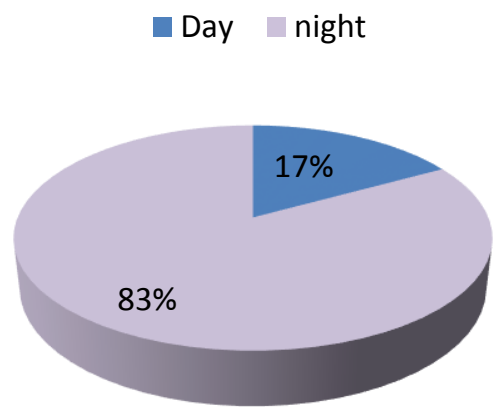

Figure 1. Energy consumption between the hours of the day and the night

\subsection{Results of the technical evaluation}

Analyzing the recording of data obtained during the measurements it can be verified that of the three lines the one with the highest consumption corresponds to L1 and then L2 from Monday to Friday, but on Saturday and Sunday the L2 does not have Consumption, while the L 3 is maintained at 2.5 Amperes (A) and is where the greatest energy expenditure occurs on weekends. At the same time it can be contacted that the morning peak of consumption takes place at 11:00 a.m., starting to lower until 14:00 p.m which starts again to increase consumption; but never reaches the level of 11:00 a.m.

By analyzing the recorded data it was possible to verify that during the day the line-toneutral voltage is stable between $120 \mathrm{~V}$ and $124 \mathrm{~V}$; but line to line never exceeds $214 \mathrm{~V}$, and is maintained between $205 \mathrm{~V}$ and $214 \mathrm{~V}$. The highest level of tension is experienced from 06:00 am to $07: 00 \mathrm{am}$, as well as from 5:00 pm to 6:00 p.m. the lowest fluctuations are experienced from 08:00 a.m and are kept throughout the day until 4:00 p.m, with a voltage between 205V at 214V.

\subsection{Current profile evaluation}

The evaluations made it possible to verify that after the installation of the photovoltaic power plant the current decreased, except on Wednesday and Thursday, which coincided with cloudy and rainy days, with very diffuse solar radiation and little generation of photovoltaic electricity. Figure 2 shows the daily behavior of the current in (A) a weekly analysis is done before and after the installation of the photovoltaic plant.
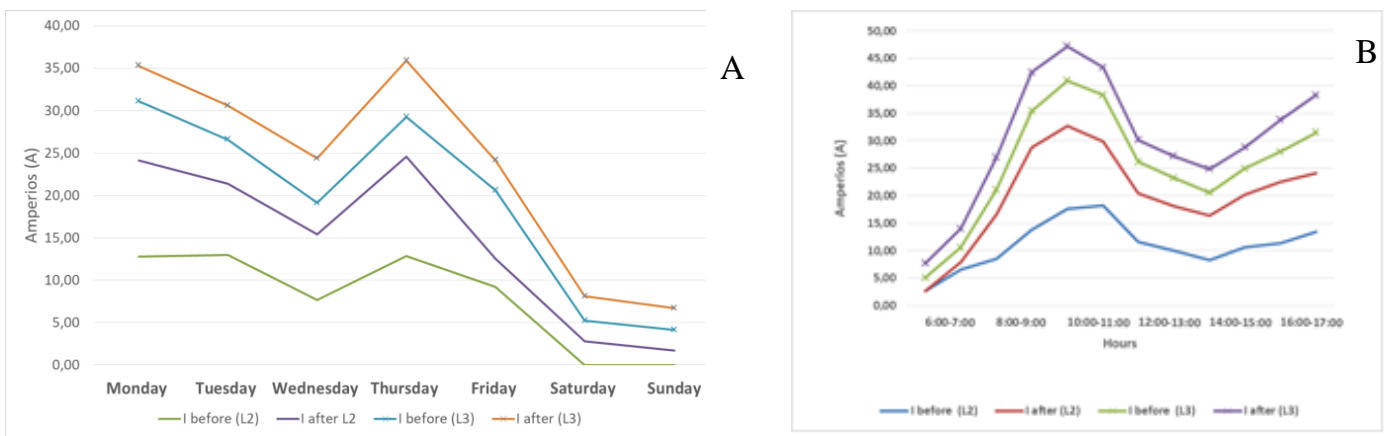

Figure 2. Daily behavior of the current before and after the installation

Arauz, W. M. S., Cedeño, G. I., Chávez, S. S., Pérez, A. V., \& Gámez, M. R. (2017). Microgrid with a $3.4 \mathrm{kWp}$ photovoltaic system in the Universidad Técnica de Manabí. International Journal of Physical Sciences and Engineering, 1(2), 11-20. https://doi.org/10.21744/ijpse.v1i2.34 
Figure 2 (B) shows the hourly behavior of current during the hours of the day, being able to observe that before the installation of the photovoltaic power plant the greater current consumption was given at 11:00 a.m. to 12:00 a.m., but Then when the installation of the plant was carried out the current decreased considerably and this occurs because it corresponds to the schedule where the highest solar radiation occurs on the photovoltaic modules.

\subsection{Evaluation of the tension profile}

It is important to consider that the measurements made before installing the photovoltaic plant showed that in no case did the measured LL voltage in the building exceeds $214 \mathrm{~V}$, rather it ranged between $205 \mathrm{~V}$ and $214 \mathrm{~V}$. After the photovoltaic power plant It was possible to verify that the level of the tension increased until the $216 \mathrm{~V}$ improving in this sense. Figure 3 shows the analysis of the daily behavior of the voltage generated before and after the installation of the photovoltaic power plant, the difference observed on Thursday was related to the incidence of solar radiation on the module that diminished to be a cloudy and rainy day, despite that it shows improvement in the tension levels

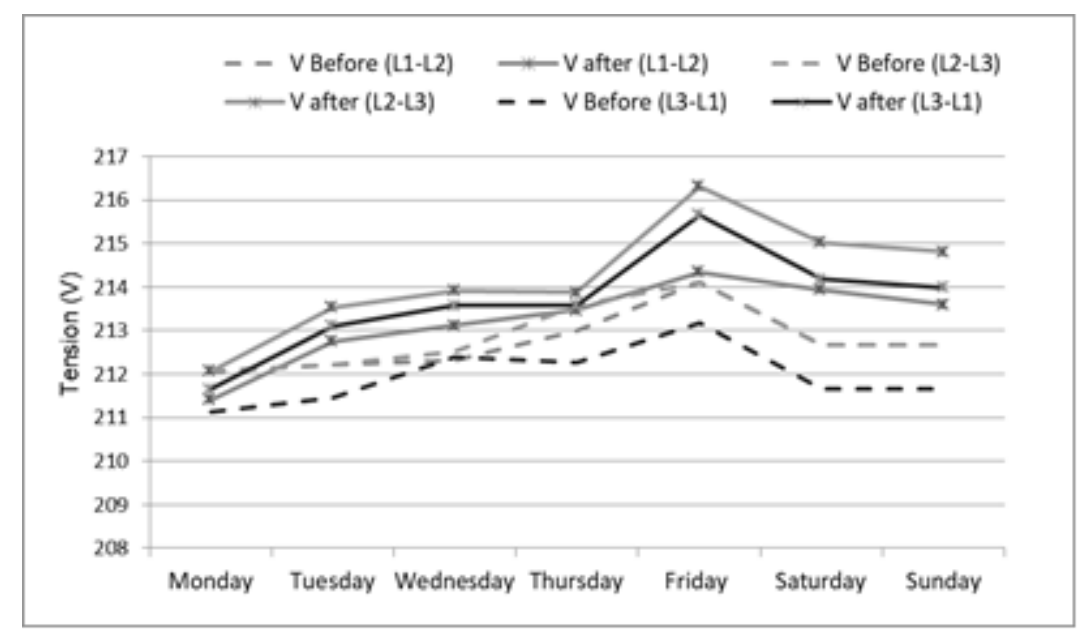

Figure 3. Daily behavior

It can be clearly seen that after the installation of the photovoltaic power station at all times the voltage profile has improved, which previously only exceeded $210 \mathrm{~V}$ and can now reach up to $216 \mathrm{~V}$. Currently the lowest levels are $212 \mathrm{~V}$ that is experienced from 9:00 a.m. to 12:00 p.m. and between 14:00 p.m. and 4:00 p.m. In Figure 4 it is possible to observe the improvement of the tension during the hours of the day. 


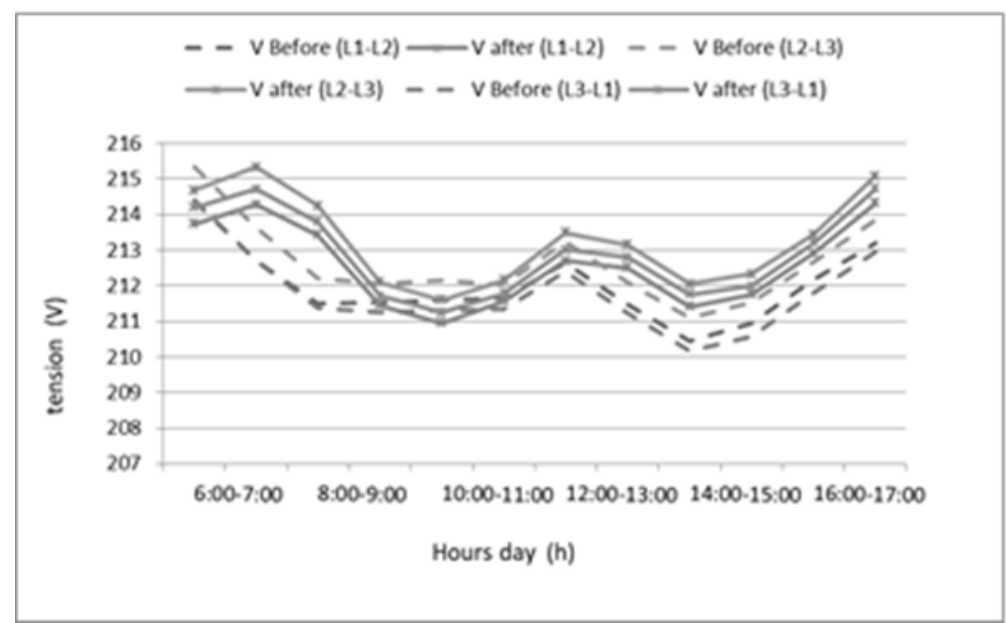

Figure 4. Voltage in hours of day

\subsection{Assessment of apparent power profile}

The measurements made allow appreciating the behavior of the actual consumption that the building has before and after the installation of the photovoltaic plant. It can be clearly seen that the actual energy consumption of the centralized grid is higher before installing the photovoltaic power plant, with a reduction corresponding to the contribution of solar energy.

Prior to the installation of the photovoltaic power plant, the hours of energy consumption of the conventional grid were experienced between 10:00 a.m. to 12:00 am. After the installation of the technology, it can be seen that these values of consumption decreased by the contribution that gives the plant and the same happens in most schedules. After observing the values of consumption previously we can deduce that the contribution that is obtained from the photovoltaic power plant reduces the consumption levels of the conventional electricity grid. figure 5 shows the hourly behavior of the apparent power before and after the photovoltaic power plant.

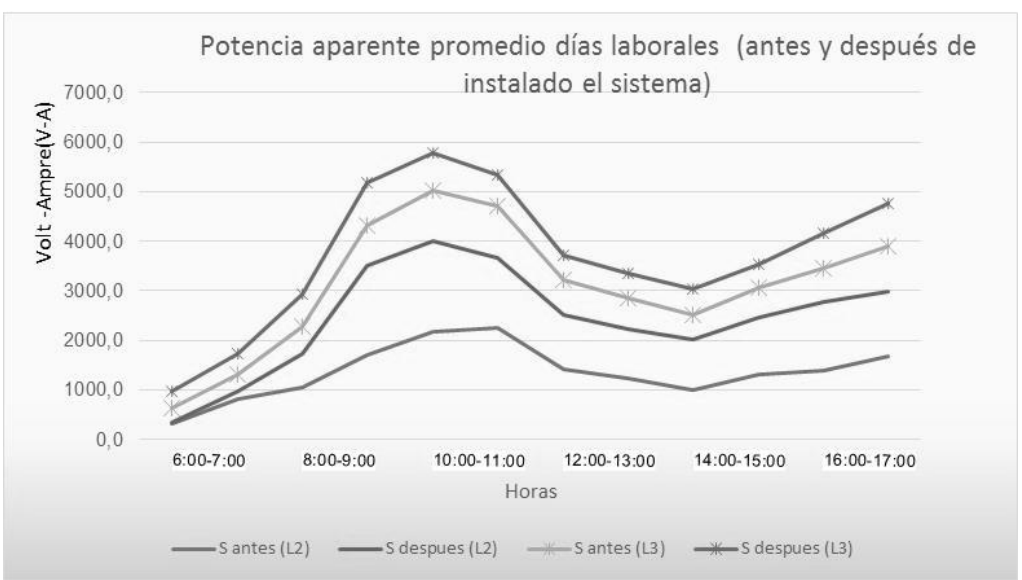

Figura 5. Comportamiento horario de la potencia aparente

As can be seen, the levels of apparent power have improved with the installation of the photovoltaic power plant.

The experience gained in the evaluation of the photovoltaic micro-grid has allowed researchers and students of the electric field to continue to deepen the subject so that this

Arauz, W. M. S., Cedeño, G. I., Chávez, S. S., Pérez, A. V., \& Gámez, M. R. (2017). Microgrid with a $3.4 \mathrm{kWp}$ photovoltaic system in the Universidad Técnica de Manabí. International Journal of Physical Sciences and Engineering, 1(2), 11-20. https://doi.org/10.21744/ijpse.v1i2.34 
experience can be applied in the province in companies and homes knowing the levels of solar radiation that exist.

\section{Conclusion}

Provide a statement that what is expected, as stated in the "Introduction" chapter can The research made it possible to verify that the introduction of the microrred based on a photovoltaic power plant connected to the low voltage grid, favored the improvement of the voltage, current and apparent power profiles, while at the same time favoring the reduction of the consumption of electric energy of the conventional grid, with the potential to reduce the

amount of the electric bill, contributing to the reduction of oil consumption and $\mathrm{CO} 2$ emissions to the atmosphere

\section{Acknowledgement}

This research is realized thanks to the support of the direction of the University financing the project of the microgrids. 


\section{References}

1. Carlos Bordons, Félix García-Torres, Luis Valverde. Gestión (2015) Óptima de la Energía en Microrredes con Generación Renovable. Revista Iberoamericana de Automática e Informática industrial 12 117-132. www.sciencedirect.com

2. Lasseter, R. H. (2002). "Microgrids." IEEE Power Eng Soc Transm Distrib Conf 305-8 I.

3. L. I. L, Eguiluz. J.C, Mañana. M and P. Sánchez (2006). "Eficiencia Energética y Calidad de Suministro Eléctrico." Dpto. de Ingeniería Eléctrica y Energética, Universidad de Cantabria, Santander.

4. David B. Chiesa and Spencer K. Zirkelbach (2014). "Microgrids Help More Than They Hurt." v i e w p o i n t. IEEE Electrification Magazine / MARCH 2014 2325-5987/14/2014IEEE.

5. S. Hunt (2002). "Making Competition work in Electricity." New York: Wiley \& Sons.

6. NASA (2015) Surface meteorology and Solar Energy. A renewable energy resource https://eosweb.larc.nasa.gov/sse).

7. SIEMENS (2008). "SENTRON PAC 3200." Manual Power Monitoring Device. Order number: http://w5.siemens.com/spain/web/es/building_technologies/sp_baja_tension

8. Karady, G. and X. Zhang (2011). "Sustainability and resilience of electric supply in an urban environment." Power Systems Conference and Exposition (PSCE) IEEE/PES 1-3.

9. Núñez M. Oscar, Ortiz V. Diego and P.-B. Rodrigo (2013). "Microrredes en la red eléctrica del futuro. Caso Huatacondo." Ciencia y Tecnología, 29(2): 1-16, 2013. ISSN: 0378-0524.

10. L. I. L, Eguiluz. J.C, Mañana. M and P. Sánchez (2006). "Eficiencia Energética y Calidad de Suministro Eléctrico." Dpto. de Ingeniería Eléctrica y Energética, Universidad de Cantabria, Santander.

11. Vivas, F. E. V., Cuello, R. L. C., Macías, D. M., \& Rosado, G. P. (2017). Elaboration of Essential Oil from the Oregano for Medicinal Use Sheet. International Journal of Physical Sciences and Engineering (IJPSE), 1(1), 81-87.

12. Jain, P., Billaiya, R., \& Malaiya, S. (2017). A Correlational Analysis of Academic Stress in Adolescents in Respect of Socio-Economic Status. International Journal of Physical Sciences and Engineering (IJPSE), 1(1), 68-71.

13. Castillo, G. A. L., Álava, L. A. C., Fernández, M. C., \& Llanes, M. V. (2017). Roadmap for the Introduction of Smart Grids in Ecuador. International Journal of Physical Sciences and Engineering (IJPSE), 1(2), 1-10.

14. Ogunsiji, A. S., \& Ladanu, W. K. (2017). A Theoretical Study of Performance Measures in the Strategic and Corporate Entrepreneurships of Firms. International Journal of Physical Sciences and Engineering (IJPSE), 1(1), 72-80.

15. Arauz, W. M. S., Cedeño, G. I., Chávez, S. S., Pérez, A. V., \& Gámez, M. R. (2017). Microgrid With a 3.4 kWp Photovoltaic System in the Universidad Técnica de Manabí. International Journal of Physical Sciences and Engineering (IJPSE), 1(2), 11-20.

16. سدل يمان الـر ضى محمد, I., \& Mohammed Elmardi Suleiman Khayal, O. (2017). Deflection of Laminated Composite Plates Using Dynamic Relaxation Method.

17. Suleiman, O. M. E. (2017). Linear Deflection of Laminated Composite Plates using Dynamic Relaxation Method. jiA, 6(2), 1.

18. Suleiman, O. M. E. (2017). Deflection of Laminated Composite Plates Using Dynamic Relaxation Method. International Journal of Physical Sciences and Engineering (IJPSE), 1(1), 40-53.

19. Omer, A. M. (2017). Sustainable Development and Environmentally Friendly Energy Systems. International Journal of Physical Sciences and Engineering (IJPSE), 1(1), 1-39.

Arauz, W. M. S., Cedeño, G. I., Chávez, S. S., Pérez, A. V., \& Gámez, M. R. (2017). Microgrid with a $3.4 \mathrm{kWp}$ photovoltaic system in the Universidad Técnica de Manabí. International Journal of Physical Sciences and Engineering, 1(2), 11-20. https://doi.org/10.21744/ijpse.v1i2.34 


\section{Biography of Authors}

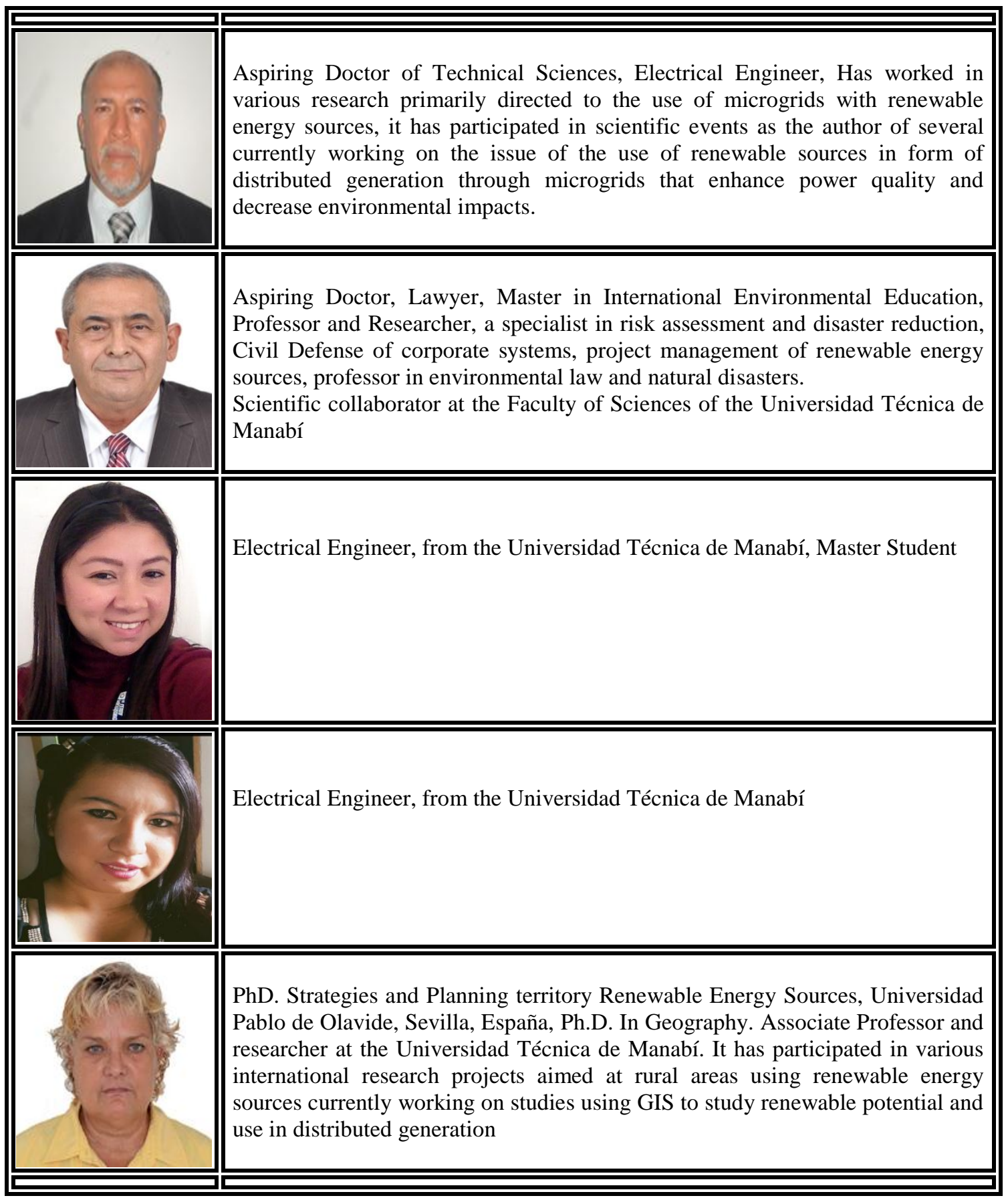

